\title{
Lactic acid fermentation as a tool to enhance the functional features of Echinacea spp
}

\author{
Carlo Giuseppe Rizzello ${ }^{1}$ Rossana Coda ${ }^{1}$, Davinia Sánchez Macías², Daniela Pinto ${ }^{3}$, Barbara Marzani \\ Pasquale Filannino ${ }^{1}$, Giammaria Giuliani ${ }^{3}$, Vito Michele Paradiso ${ }^{1}$, Raffaella Di Cagno ${ }^{1 *}$ and Marco Gobbetti ${ }^{1}$
}

\begin{abstract}
Background: Extracts and products (roots and/or aerial parts) from Echinacea ssp. represent a profitable market sector for herbal medicines thanks to different functional features. Alkamides and polyacetylenes, phenols like caffeic acid and its derivatives, polysaccharides and glycoproteins are the main bioactive compounds of Echinacea spp. This study aimed at investigating the capacity of selected lactic acid bacteria to enhance the antimicrobial, antioxidant and immune-modulatory features of E. purpurea with the prospect of its application as functional food, dietary supplement or pharmaceutical preparation.
\end{abstract}

Results: Echinacea purpurea suspension (5\%, wt/vol) in distilled water, containing $0.4 \%(\mathrm{wt} / \mathrm{vol})$ yeast extract, was fermented with Lactobacillus plantarum POM1, 1MR20 or C2, previously selected from plant materials. Chemically acidified suspension, without bacterial inoculum, was used as the control to investigate functional features. Echinacea suspension fermented with $L b$. plantarum C2 exhibited a marked antimicrobial activity towards Gram-positive and -negative bacteria. Compared to control, the water-soluble extract from Echinacea suspension fermented with Lactobacillus plantarum 1MR20 showed twice time higher radical scavenging activity on DPPH. Almost the same was found for the inhibition of oleic acid peroxidation. The methanol extract from Echinacea suspension had inherent antioxidant features but the activity of extract from the sample fermented with strain 1MR20 was the highest. The antioxidant activities were confirmed on Balb 3T3 mouse fibroblasts. Lactobacillus plantarum C2 and 1MR20 were used in association to ferment Echinacea suspension, and the water-soluble extract was subjected to ultra-filtration and purification through RP-FPLC. The antioxidant activity was distributed in a large number of fractions and proportional to the peptide concentration. The antimicrobial activity was detected only in one fraction, further subjected to nano-LC-ESI-MS/MS. A mixture of eight peptides was identified, corresponding to fragments of plantaricins PInH or PInG. Treatments with fermented Echinacea suspension exerted immunemodulatory effects on Caco-2 cells. The fermentation with $\mathrm{Lb}$. plantarum 1MR20 or with the association between strains C2 and 1MR20 had the highest effect on the expression of TNF-a gene.

Conclusions: $E$. purpurea subjected to lactic acid fermentation could be suitable for novel applications as functional food dietary supplements or pharmaceutical preparations.

\section{Background}

The genus Echinacea belongs to the Asteraceae family and comprises a group of perennial prairie wildflowers, which are native to central grasslands of North America. The cultivation is mainly extended throughout United States, Canada and Europe (especially Germany). Echinacea angustifolia DC, Echinacea pallida (Nutt.) and, especially,

\footnotetext{
*Correspondence: raffaella.dicagno@uniba.it

'Dipartimento di Scienze del Suolo, della Pianta e degli Alimenti, University of Bari, Via G. Amendola 165/a, 70126 Bari, Italy

Full list of author information is available at the end of the article
}

Echinacea purpurea (L.) Moench [1] are the species more widespread [2]. High costs and scarce standardization of the spontaneous collections [3] had favored the expansion of the cultivation of Echinacea ssp. Extracts and products (roots and/or aerial parts) from the whole plant represent a profitable market sector for herbal medicines in North America and Europe [2]. The cultivation of Echinacea spp. in Italy corresponds to ca. 15 - 20 ha, with a production of ca. 9 - 12 tons of dried roots per year, but the demand is at least twice [3].

\section{Biomed Central}

(c) 2013 Rizzello et al.; licensee BioMed Central Ltd. This is an Open Access article distributed under the terms of the Creative Commons Attribution License (http://creativecommons.org/licenses/by/2.0), which permits unrestricted use, distribution, and reproduction in any medium, provided the original work is properly cited. 
Alkamides and polyacetylenes [4], phenols like caffeic acid and its derivatives (caftaric, chlorogenic and cichoric acids, and cynarin and echinacoside) [5], polysaccharides [6] and glycoproteins [7] are the main bioactive compounds of Echinacea spp. Since this large variety of inherent functional compounds, the assignment of functional features to a defined class of chemical compounds is not always possible. Antioxidant, anti-inflammatory, antimicrobial and immune-modulatory activities are the main functional features of this herbal medicine. Alkamides have medicinal efficacy $[8,9]$ and, more in general, extracts of $E$. angustifolia show therapeutic activity on adults who practice enduring sports [10]. Cichoric acid possesses immune-stimulatory [11], antiyaluronidase [12] and antiviral [5] activities, promotes the in vitro and in vivo phagocyte activity, protects collagen from free radical induced degradation [13], and inhibits HIV-1 integrase and replication $[14,15]$. Echinacoside protects the collagen from reactive oxygen species [13], and possesses antioxidant [16], anti-inflammatory and cicatrizing activities [17]. Preparations of E. purpurea are used for treatments of respiratory, urinary, viral and cutaneous infections, which are mainly related to deficiencies of the immune response [17-19]. Extracts from the same species had bactericidal activity towards Staphylococcus sp., and killed WEHI 164 tumor cells and the parasite Leishmania enriettii or Candida albicans [20]. Under near UV irradiation (phototoxicity), hexane extracts of Echinacea spp. inhibited the growth of numerous yeasts such as Saccharomyces cerevisiae, Candida shehata, Candida kefyr, C. albicans, Candida steatulytica and Candida tropicalis [21]. Extracts from E. purpurea protected immune-suppressed mice towards systemic infections by Listeria monocytogenes and C. albicans [22]. In vivo studies on mice, rat and humans showed the absence of toxicity of extracts of Echinacea spp., even when they were administered intravenously at high doses [23].

Based on the above description, the need to better define and, if possible, to enhance the activity of bioactive compounds emerges as a priority to get standardized market products (e.g., tablets, capsules and hydroalcoholic extracts) for well-known or novel applications [1]. In compliance with this aim, a biotechnology approach, which is based on the use of plant cell cultures of E. angustifolia, was promoted by FAO, as an alternative method to produce secondary metabolites for food and pharmaceutical applications [24]. On the other hand, lactic acid fermentation of Echinacea spp. may also have the potential to standardize the functional features of the raw matrix and it may increase the bioavailability of certain compounds and/or allow the synthesis of novel substances to be used for functional preparations. Overall, the synthesis of bioactive metabolites having therapeutic properties is largely documented during lactic fermentation of plant materials [25-27].
To the best of our knowledge, no studies have already considered the use of lactic acid fermentation to enhance the functional features of Echinacea spp. This study aimed at investigating the capacity of selected lactic acid bacteria to enhance the antimicrobial, antioxidant and immune-modulatory features of E. purpurea with the prospect of its application as functional food, dietary supplement or pharmaceutical preparation.

\section{Results}

\section{Echinacea fermentation}

Echinacea powder suspension (ES) (5\%, wt/vol) in distilled water or grape must ( $1 \%$ of total carbohydrates) allowed a very poor growth of Lactobacillus plantarum POM1, $1 \mathrm{MR} 20$ and $\mathrm{C} 2$. When yeast extract $(0.4 \%$, wt/vol) was added to suspension in distilled water, the cell density of the above strains increased from ca. $1 \times 10^{8} \mathrm{CFU} / \mathrm{ml}$ to $2.2 \pm 0.1-4.7 \pm 0.3 \times 10^{9} \mathrm{CFU} / \mathrm{ml}$. All further experiments referred to these optimized culture conditions. $L b$. plantarum 1MR20, C2 and POM1 caused an almost similar acidification. After 24 of fermentation, the values of $\mathrm{pH}$ of ES decreased from $5.21 \pm 0.22$ (control) to $4.35 \pm$ $0.21,4.18 \pm 0.18$, and $4.27 \pm 0.13$, respectively for $L b$. plantarum 1MR20, C2 and POM1.

\section{Antimicrobial and antioxidant activities}

The antimicrobial and antioxidant activities of control (ES-CT) and fermented ES were assayed in vitro. The inhibition of various indicator strains is shown in Table 1. No antimicrobial activity was found for ES-CT. ES fermented with $L b$. plantarum 1MR20-ES showed a slight inhibition, only towards Bacillus megaterium F6. On the contrary, ES fermented with Lb. plantarum C2 and POM1 had rather wide and common spectrum of activity. The only exception were Enterococcus durans DSM20633, only inhibited by $L b$. plantarum C2, and Lactobacillus sakei SAL1, Candida krusei DSM 3433 and Penicillium roqueforti DPPMA1, which were not affected. The antimicrobial activity of ES fermented by Lb. plantarum $\mathrm{C} 2$ was the most intense.

First, the antioxidant activity of fermented ES was assayed as radical scavenging activity on 1,1-diphenyl-2picrylhydrazyl (DPPH) radical and as inhibition of oleic acid peroxidation. The analyses were carried out using both water-soluble (WSE) and methanol (ME) extracts. During radical scavenging assay, the colored stable $\mathrm{DPPH}$ radical is reduced to non-radical DPPH-H, when in the presence of an antioxidant or a hydrogen donor. $\mathrm{DPPH}$ radical without antioxidants was stable over the time. Under the assay conditions, the $100 \%$ of activity corresponds to the complete scavenging of DPPH radical (50 $\mu \mathrm{M}$ final concentration) after $10 \mathrm{~min}$ of incubation with the antioxidant compounds. According to previous studies $[27,28]$, the color intensity of $\mathrm{DPPH}^{*}$ showed a 
Table 1 Inhibitory spectrum of the Echinacea suspension (ES)

\begin{tabular}{|c|c|c|c|c|c|}
\hline Microorganism & $\begin{array}{l}\text { ES- } \\
\text { CT }\end{array}$ & $\begin{array}{l}\text { 1MR20- } \\
\text { ES }\end{array}$ & $\begin{array}{l}\text { C2- } \\
\text { ES }\end{array}$ & $\begin{array}{l}\text { POM1- } \\
\text { ES }\end{array}$ & $\begin{array}{l}\text { 1MR20/ } \\
\text { C2-ES }\end{array}$ \\
\hline Escherichia coli DSM 30083 & - & - & ++ & + & ++ \\
\hline $\begin{array}{l}\text { Enterococcus durans DSM } \\
20633\end{array}$ & - & - & ++ & - & ++ \\
\hline $\begin{array}{l}\text { Yersinia enterocolitica DSM } \\
4780\end{array}$ & - & - & +++ & ++ & +++ \\
\hline Bacillus megaterium F6 & - & + & $\begin{array}{c}+++ \\
+\end{array}$ & +++ & ++++ \\
\hline $\begin{array}{l}\text { Enterobacter aerogenes DSM } \\
30053\end{array}$ & - & - & +++ & + & +++ \\
\hline $\begin{array}{l}\text { Weissella confusa DSM } \\
20196\end{array}$ & - & - & +++ & ++ & +++ \\
\hline $\begin{array}{l}\text { Leuconostoc lactis DSM } \\
20202\end{array}$ & - & - & +++ & +++ & +++ \\
\hline Lactobacillus sakei SAL1 & - & - & - & - & - \\
\hline $\begin{array}{l}\text { Propionibacterium jensenii } \\
\text { DSM } 20535\end{array}$ & - & - & ++ & + & ++ \\
\hline Candida krusei DSM 3433 & - & - & - & - & - \\
\hline $\begin{array}{l}\text { Penicillium roqueforti } \\
\text { DPPMA1 }\end{array}$ & - & - & - & - & - \\
\hline
\end{tabular}

Inhibitory activity was scored as follows: -: no inhibition; +: inhibition zone diameter 0.5-1 mm; ++: inhibition zone diameter 1-2.5 mm; +++: inhibition zone diameter 2.5-3.5 mm; ++++: inhibition zone diameter $>3.5 \mathrm{~mm}$. ES was fermented for $24 \mathrm{~h}$ at $30^{\circ} \mathrm{C}$ with Lactobacillus plantarum 1 MR20 (1MR20-ES), C2 (C2-ES) and POM1 (POM1-ES), and with the association between strains 1MR20 and C2 (1MR20/C2-ES), as determined by agar diffusion assay. The chemically acidified ES, without bacterial inoculum, and incubated for $24 \mathrm{~h}$ at $30^{\circ} \mathrm{C}$ (ES-CT), was the control.

logarithmic decline when it was in the presence of butylated hydroxytoluene (BHT). The activity of WSE was lower than BHT, which was used as the positive control (Table 2). WSE from ES-CT had a radical scavenging activity towards the stable radical DPPH of $21.0 \pm 0.2 \%$. Fermentation significantly $(P<0.05)$ increased the radical scavenging activity of all WSE. The increase was slight for ES fermented with $L b$. plantarum C2 and POM1, but almost twice when strain 1MR20 was used. Compared to WSE, the ME from ES-CT had a higher radical scavenging activity. The antioxidant activities of $\mathrm{ME}$ from ES fermented with $L b$. plantarum $\mathrm{C} 2$ and POM1 were slightly lower compared to ES-CT. On the contrary, the radical scavenging activity of ME from the ES fermented with strain 1MR20 was higher than that found for ES-CT and not significantly $(P>0.05)$ different with respect to BHT. Lipid peroxidation is thought to proceed via radical mediated abstraction of hydrogen atoms from methylene carbons in polyunsaturated fatty acids [29]. The antioxidant activity of WSE from fermented and non-fermented ES was slightly lower than that of BHT used as the positive control. Compared to ES-CT, no significant $(P>0.05)$ differences were found for the ES fermented with $L b$. plantarum 1MR20. The values for the ES fermented with the other two strains were significantly $(P<0.05)$ lower. The inhibition of the linoleic acid peroxidation by ME was similar to that of $\alpha$-tocopherol and lower than that of BHT. No significant $(P>0.05)$ differences were found among ES-CT and fermented ES.

To further investigate the capacity of ES to act as radical scavenger, cultured mouse fibroblasts were grown in the presence of freeze-dried fermented and nonfermented samples. Afterwards, mouse fibroblasts were treated with hydrogen peroxide. Cell viability was assayed through the capacity of functional mitochondria to catalyze the reduction of MTT to formazan salt via mitochondrial dehydrogenases. Compared to negative control $(55.4 \pm 2.1 \%$ of cell viability after oxidative stress), $\alpha$-tocopherol and all ES significantly $(P<0.05)$ increased cell survival (Figure 1). In particular, ES fermented with $L b$. plantarum 1MR20, especially at

Table 2 Radical scavenging activity towards $\mathrm{DPPH}^{\bullet}$ and linoleic acid peroxidation inhibitory activity

\begin{tabular}{|c|c|c|c|c|}
\hline & \multicolumn{2}{|c|}{ WSE } & \multicolumn{2}{|c|}{ ME } \\
\hline & $\begin{array}{c}\text { DPPH radical scavenging } \\
\text { activity }\end{array}$ & $\begin{array}{c}\text { Lipid peroxidation inhibitory } \\
\text { activity }\end{array}$ & $\begin{array}{c}\text { DPPH radical scavenging } \\
\text { activity }\end{array}$ & $\begin{array}{c}\text { Lipid peroxidation inhibitory } \\
\text { activity }\end{array}$ \\
\hline$\overline{\mathrm{BHT}}$ & $63.7 \pm 0.5^{d}$ & $93.8 \pm 0.3^{d}$ & $78.5 \pm 0.3^{c}$ & $93.8 \pm 0.2^{c}$ \\
\hline a -tocopherol & nd & $91.9 \pm 0.3^{b}$ & nd & $91.9 \pm 0.2^{\mathrm{a}}$ \\
\hline ES-CT & $21.0 \pm 0.2^{\mathrm{a}}$ & $92.9 \pm 0.2^{c}$ & $74.8 \pm 0.4^{b}$ & $91.1 \pm 0.3^{b}$ \\
\hline 1MR20-ES & $41.5 \pm 0.4^{c}$ & $92.7 \pm 0.3^{c}$ & $79.1 \pm 0.2^{c}$ & $90.8 \pm 0.3^{b}$ \\
\hline C2-ES & $25.6 \pm 0.4^{b}$ & $92.0 \pm 0.4^{b}$ & $72.3 \pm 0.3^{a}$ & $91.4 \pm 0.1^{b}$ \\
\hline POM1-ES & $24.6 \pm 0.3^{b}$ & $90.5 \pm 0.2^{\mathrm{a}}$ & $75.3 \pm 0.2^{b}$ & $90.2 \pm 0.2^{\mathrm{a}}$ \\
\hline 1MR20/C2-ES & $41.7 \pm 0.2^{c}$ & $92.9 \pm 0.1^{c}$ & $79.3 \pm 0.1^{c}$ & $91.0 \pm 0.2^{b}$ \\
\hline
\end{tabular}

Data are the mean of three independent analyses.

${ }^{a-d}$ Values in the same row with different superscript letters differ significantly $(P<0.05)$.

Antioxidant activity of the water-soluble (WSE) and methanol (ME) extracts of Echinacea suspension (ES) fermented for $24 \mathrm{~h}$ at $30^{\circ} \mathrm{C}$ with Lactobacillus plantarum 1MR20 (1MR20-ES), C2 (C2-ES) and POM1 (POM1-ES), and with the association between strains 1 MR20 and C2 (1MR20/C2-ES). The chemically acidified ES, without bacterial inoculum, and incubated for $24 \mathrm{~h}$ at $30^{\circ} \mathrm{C}(\mathrm{ES}-\mathrm{CT})$, was the control. Butylatedhydroxytoluene (BHT) and a-tocopherol were used as positive controls. 


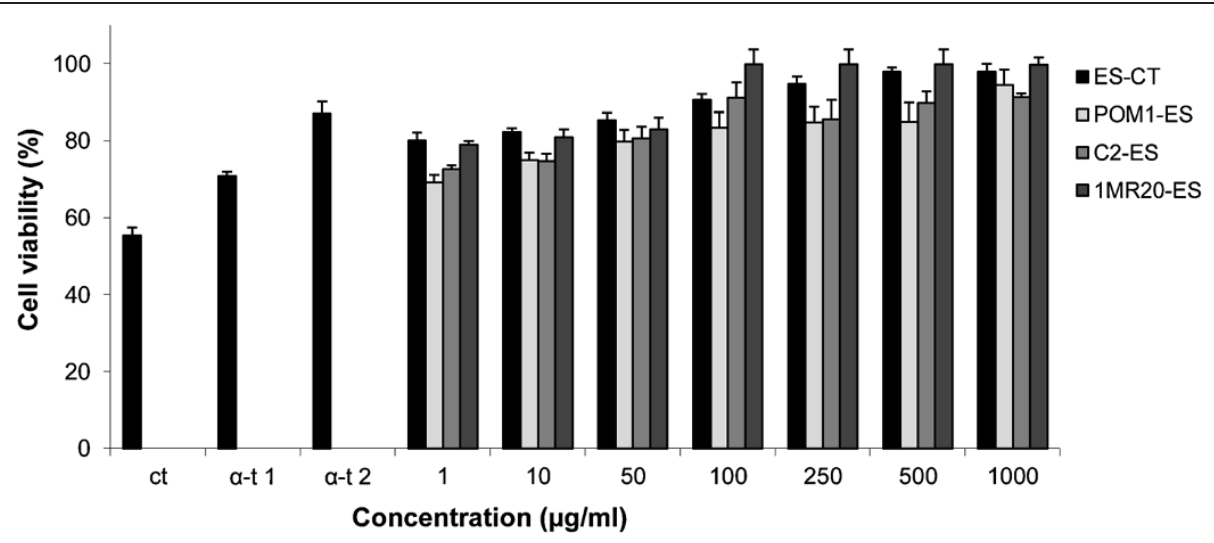

Figure 1 Cell viability of mouse fibroblasts. Effect of different concentrations (1 - $1000 \mu \mathrm{g} / \mathrm{ml}$ ) of freeze-dried Echinacea suspension (ES) on cell viability of mouse fibroblasts cultured in Dulbecco's Modified Eagle Medium (DMEM), and incubated with re-suspended freeze dried ES for $16 \mathrm{~h}$. Oxidative stress was artificially induced by incubating cultured cells with $150 \mu \mathrm{M}$ hydroxide peroxide for $2 \mathrm{~h}$. The percentage of viable cells with respect to untreated cultures was measured through the 3-(4,5-dimethylthiazol-2-yl)-2,5-diphenyltetrazolium bromide (MTT) assay. ES fermented for 24 h at $30^{\circ} \mathrm{C}$ with Lactobacillus plantarum 1MR20 (1MR20-ES), C2 (C2-ES) and POM1 (POM1-ES), and with the association between strains 1 MR20 and C2 (1MR20/C2-ES) were assayed. ES-CT, chemically acidified ES, without bacterial inoculum, and incubated for $24 \mathrm{~h}$ at $30^{\circ} \mathrm{C}$, was the control. a-Tocopherol (a-t1, $250 \mathrm{\mu g} / \mathrm{ml}$, and $\mathrm{a}-\mathrm{t} 2,500 \mathrm{\mu g} / \mathrm{ml}$ ) was used as the positive control. Data are the means of three independent experiments twice analysed.

concentrations of 100 and $250 \mu \mathrm{g} / \mathrm{ml}$, induced the highest cell viability. The activity was also significantly $(P<0.05)$ higher than that found with $\alpha$-tocopherol at both concentrations of 250 and $500 \mu \mathrm{g} / \mathrm{ml}$. Overall, no significant $(P>0.05)$ differences were found among ES$\mathrm{CT}$ and ES fermented with $L b$. plantarum $\mathrm{C} 2$ and POM1.

Based on the above results, $L b$. plantarum $\mathrm{C} 2$ and $1 \mathrm{MR} 20$, which, respectively, showed the highest antimicrobial and antioxidant activities were used in association as mixed starter to ferment ES. The antimicrobial and antioxidant activities were confirmed (Tables 1 and 2). Since methanol extractable compounds (e.g., polyphenols), which are responsible for antioxidant activity of Echinacea spp., were previously identified $[1,30]$, further characterizations mainly concerned the water-soluble extract.

\section{Microbiology and chemical characteristics}

After $24 \mathrm{~h}$ of fermentation, ES fermented with the association of $L b$. plantarum $\mathrm{C} 2$ and $1 \mathrm{MR} 20$ had a cell density of presumptive lactic acid bacteria of $7.5 \pm 0.4 \times 10^{9} \mathrm{CFU} / \mathrm{ml}$. The kinetic of growth was characterized as follows: $A$ of $1.3 \pm 0.01 \log \mathrm{CFU} / \mathrm{ml}, \mu_{\max }$ of $0.11 \pm 0.01 \log \mathrm{CFU} / \mathrm{ml} h$ and $\lambda$ of $0.21 \pm 0.02 \mathrm{~h}$. The $\mathrm{pH}$ of the fermented ES was $4.07 \pm 0.12$ (initial pH of $5.21 \pm 0.22$ ). The parameters of the kinetic of acidification were as follows: $\Delta \mathrm{pH}$ of $1.14 \pm 0.03$ units, $\mathrm{V}_{\max }$ of $0.16 \pm 0.01 \mathrm{dpH} / \mathrm{h}$ and $\lambda$ of $1.76 \pm 0.03 \mathrm{~h}$.

During fermentation, the concentration of glucose and fructose decreased significantly $(P<0.05)$ compared to ES-CT (ca. 50 and 25\%, respectively) (Table 3). Sucrose was not found. At the end of fermentation, the concentration of lactic and acetic acid was $20 \pm 1.2 \mathrm{mM}$ and $3.2 \pm 1.8 \mathrm{mM}$ respectively. The concentration of total phenols of ME of ES-CT and fermented ES was 9.4 \pm 0.2 and $9.9 \pm 0.1 \mathrm{mM}$, respectively. The concentration of free amino acids of the fermented ES was five times higher than that found for ES-CT. After freeze-drying, the values of moisture, protein, lipids and ash did not significantly $(P>0.05)$ vary between ES-CT and fermented ES.

Table 3 Chemical characteristics of Echinacea suspension (ES)

\begin{tabular}{lll}
\hline & ES-CT & 1MR20/C2 -ES \\
\hline Liquid matrix & $4.01 \pm 0.04$ & $4.07 \pm 0.12$ \\
\hline pH & $10.9 \pm 0.5^{\mathrm{b}}$ & $5.5 \pm 0.2^{\mathrm{a}}$ \\
Glucose (mM) & $11.84 \pm 0.6^{\mathrm{b}}$ & $8.3 \pm 0.2^{\mathrm{a}}$ \\
Fructose (mM) & - & - \\
Sucrose (mM) & $9.4 \pm 0.2^{\mathrm{a}}$ & $9.9 \pm 0.1^{\mathrm{b}}$ \\
Total phenols (mM gallic acid/ml) & $21.0 \pm 2.3$ & $20.0 \pm 1.2$ \\
Lactic acid (mM) & - & $3.2 \pm 1.8$ \\
Acetic acid (mM) & $122 \pm 5^{\mathrm{a}}$ & $612 \pm 11^{\mathrm{b}}$ \\
Free amino acids (mg/l) & & \\
\hline Freeze dried matrix & $2.28 \pm 0.15^{\mathrm{b}}$ & $2.02 \pm 0.05^{\mathrm{a}}$ \\
\hline Moisture (\%) & $15.9 \pm 0.3$ & $16.0 \pm 0.2$ \\
Protein (\% of d.m.) & $1.31 \pm 0.11$ & $1.30 \pm 0.23$ \\
Lipids (\% of d.m.) & $12.78 \pm 0.21$ & $12.82 \pm 0.19$ \\
\hline Ash (\% of d.m.) &
\end{tabular}

Data are the mean of three independent analyses. d.m.: dry matter.

${ }^{a-b}$ Values in the same row with different superscript letters differ significantly $(P<0.05)$.

ES was fermented for $24 \mathrm{~h}$ at $30^{\circ} \mathrm{C}$ with the association between Lactobacillus plantarum 1 MR20 and C2 (1MR20/C2-ES). The chemically acidified ES, without bacterial inoculum, and incubated for $24 \mathrm{~h}$ at $30^{\circ} \mathrm{C}$ (ES-CT), was the control. 


\section{Purification and identification of antimicrobial and antioxidant compounds}

Aiming at identifying bioactive compounds, WSE of ES fermented with the association between $L b$. plantarum $1 \mathrm{MR} 20$ and $\mathrm{C} 2$ was subjected to ultra-filtration (cut-off $50,30,10$ and $5 \mathrm{kDa}$ ). The antimicrobial activity was assayed using B. megaterium F6 as the indicator strain. The antioxidant activity was determined through the DPPH radical scavenging assay. All fractions from ultrafiltration showed both the activities. This suggested that molecular masses of the active compounds were lower than $5 \mathrm{kDa}$. Therefore, bioactive compounds were present in the last ultra-filtration fraction D. After digestion by trypsin, the antimicrobial activity of fraction $\mathrm{D}$ was completely lost. The antioxidant activity decreased from ca. 40 to $25 \%$. This results suggested that the above activities were totally or for the major part related to compounds of protein nature. Both antimicrobial and antioxidant activities were unaffected by heating at $100^{\circ} \mathrm{C}$ for $5 \mathrm{~min}$.

As shown through HPLC analysis, the polyphenol profiles of fractions D of WSE from ES-CT and fermented ES were almost similar (Figure 2). Notwithstanding an antioxidant effect due to polyphenols, this probably confirmed that differences between fermented and nonfermented samples had to be attributed also or mainly to compounds of protein nature. As shown through RPFPLC analysis, a marked increase of several peak areas and higher complexity was found for the peptide profile of fermented ES compared to that of ES-CT (Figure 3). Indeed, the concentration of peptides increased from $2.76 \pm 0.31$ to $13.91 \pm 1.2 \mathrm{mg} / \mathrm{ml}$. As estimated towards B. megaterium $\mathrm{F} 6$, the MIC of fraction D from fermented ES was $1.4 \pm 0.2 \mathrm{mg} / \mathrm{ml}$ of peptides.

Aiming at further purifying the antimicrobial and antioxidant compounds, fraction D was subjected to further fractionation through RP-FPLC searching for protein derivatives. Thirty-seven fractions were collected. Antimicrobial activity was only found in fraction 2 . On the contrary, the antioxidant activity largely distributed: from fractions 2 to 6 (35-55\% of DPPH radical scavenging activity) and from fractions 8 to $23(45-50 \%$ of activity). Fraction 2 was subjected to nano-LC-ESI-MS/ MS analysis, which allowed the identification of a mixture of peptides. The most intense peaks corresponded to eight different peptides, which were characterized by sequences containing 7 to 12 amino acid residues (Table 4). Except for MLAAKSSAAST (54\%) and

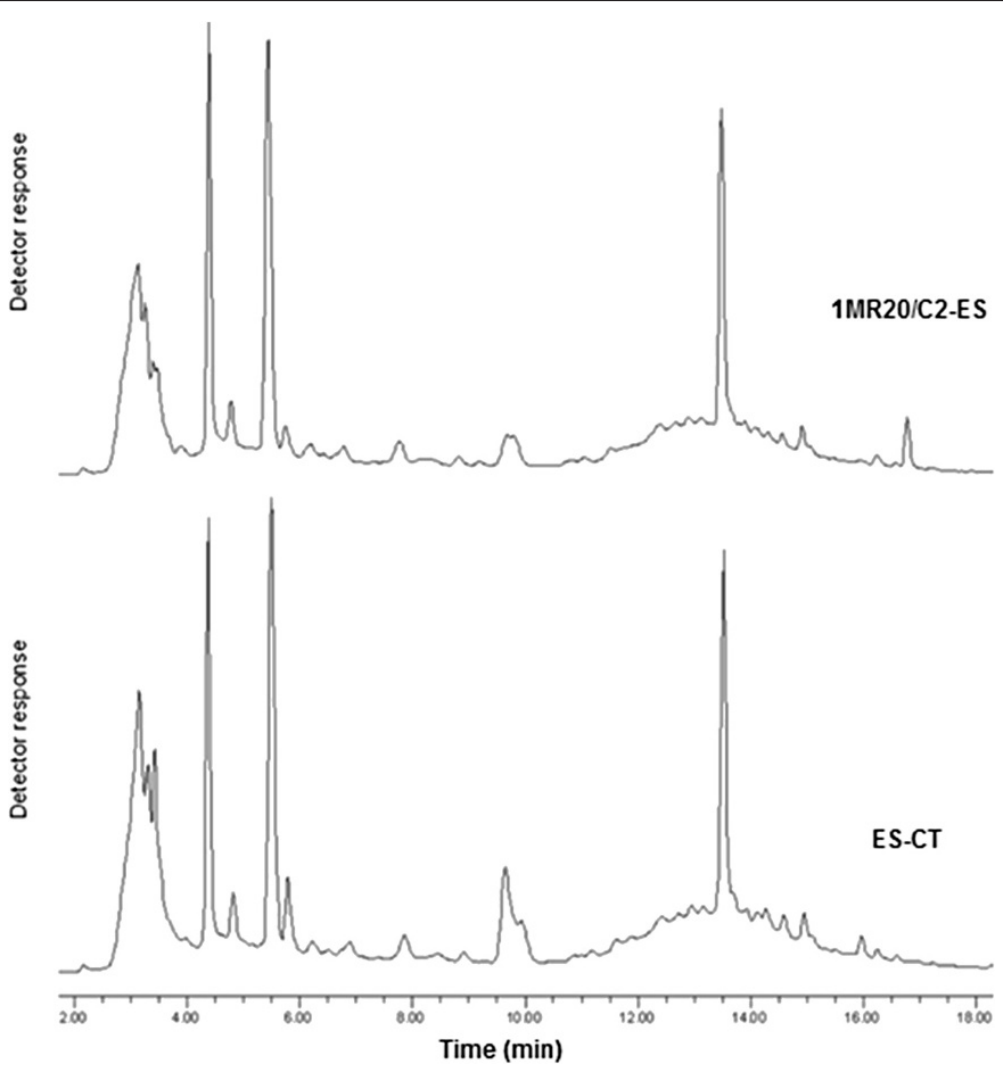

Figure 2 Polyphenols profiles after High Pressure Liquid Chromatography (HPLC) analysis. Water-soluble extract (WSE) of Echinacea suspension (ES) fermented for $24 \mathrm{~h}$ at $30^{\circ} \mathrm{C}$ with the association between Lactobacillus plantarum $1 \mathrm{MR} 20$ and C2 (1MR20/C2-ES). The chemically acidified ES, without bacterial inoculum, and incubated for $24 \mathrm{~h}$ at $30^{\circ} \mathrm{C}$ (ES-CT), was the control. 


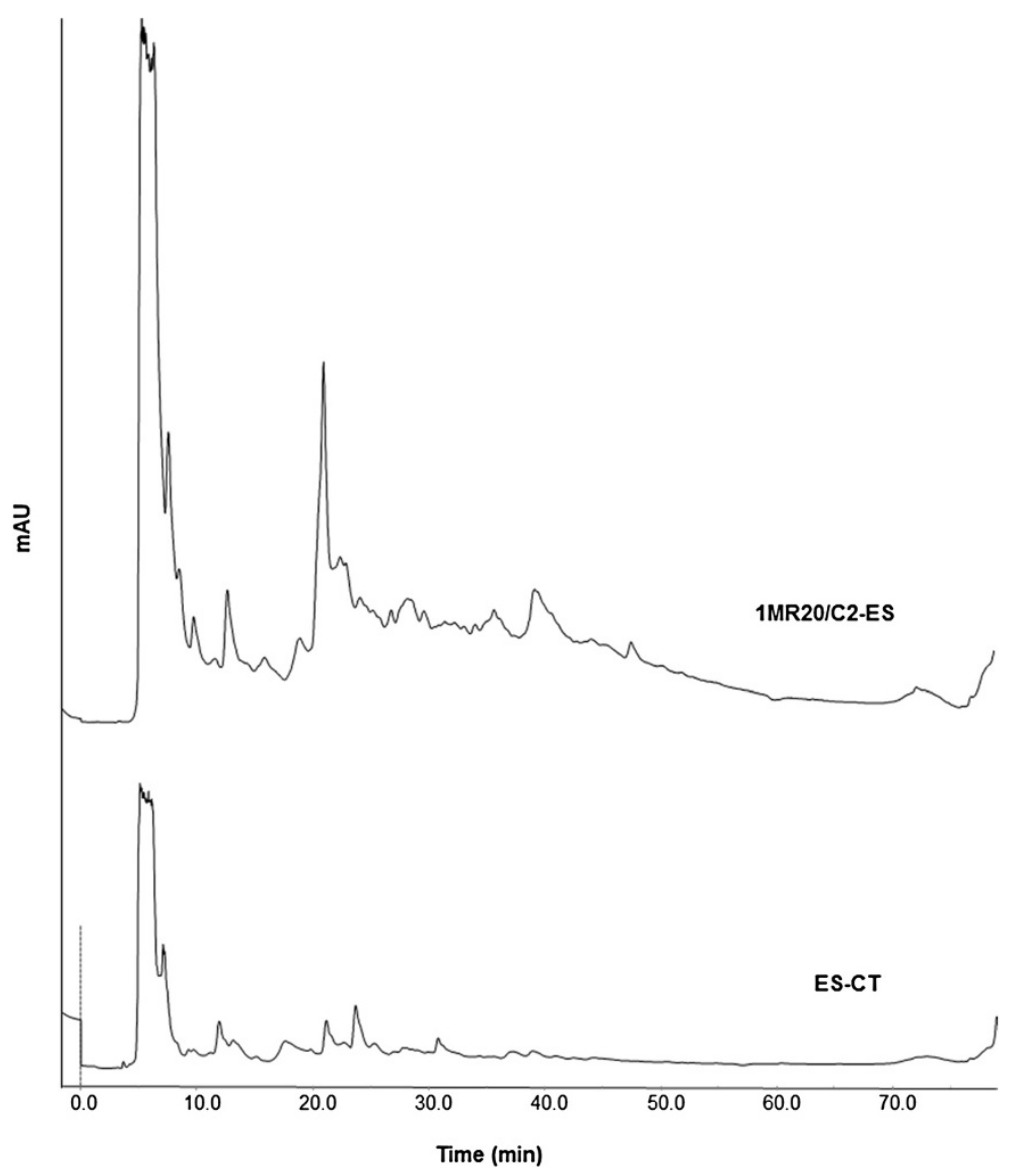

Figure 3 Peptide profiles after Reverse Phase-Fast Protein Liquid Chromatography (RP-FPLC) analysis. Water-soluble extract (WSE) of Echinacea suspension (ES) fermented for $24 \mathrm{~h}$ at $30^{\circ} \mathrm{C}$ with the association between Lactobacillus plantarum $1 \mathrm{MR} 20$ and C2 (1MR20/C2-ES). The chemically acidified ES, without bacterial inoculum, and incubated for $24 \mathrm{~h}$ at $30^{\circ} \mathrm{C}(\mathrm{ES}-\mathrm{CT})$, was the control.

VINIVLAAV (88\%), the hydrophobic ratio of all peptides was lower than 50\%. Except for ENGNTLSG (total net charge -1), neutral or positive total net charges were found for the other peptides. Five peptides were encrypted in the plantaricin $\mathrm{H}$ sequence $(\mathrm{PlnH})$. The other peptides derived from proteolysis of plantaricin $G$ (PlnG). Since antioxidant activity of WSE distributed in a very large number of RP-FPLC fractions, no further peptide identification was carried out. Based on the above results, it was hypothesized a non-specific effect

Table 4 Antimicrobial peptides

\begin{tabular}{ccccccc}
\hline $\mathbf{n .}$ & Sequence $^{\text {a }}$ & Score & Calculated mass & Expected mass & Delta & Source Protein NCBI accession number \\
\hline 1 & TASSVASTTK & 49 & 952.217 & 952.025 & -0.192 & ADE34579.1; PInH, Lb. plantarum \\
2 & TIKATKT & 38 & 762.272 & 761.909 & -0.366 & ADE34579.1; PInH, Lb. plantarum \\
3 & MLAAKSSAAST & 18 & 1037.511 & 1037.199 & -0.312 & ADE08259.1; PInH Lb. plantarum \\
4 & VSSGAEIAKI & 15 & 973.687 & 974.120 & 0.433 & ADE34579.1; PInH, Lb. plantarum \\
5 & NQMLAAKSSAAS & 13 & 1178.621 & 1178.329 & -0.292 & ADE34579.1; PInH, Lb. plantarum \\
6 & VINIVLAAV & 46 & 911.725 & 911.156 & -0.569 & ADE34578.1; PInG, Lb. plantarum \\
7 & ENGNTLSG & 35 & 791.11 & 790.786 & -0.324 & ADE34578.1; PInG, Lb. plantarum \\
8 & GNMPSGG & 12 & 612.360 & 612.669 & 0.339 & ADE34578.1; PInG, Lb. plantarum \\
\hline
\end{tabular}

a The single-letter amino acid code is used.

Sequences of peptides contained in the purified antimicrobial fraction of the water-soluble extract (WSE) of Echinacea suspension (ES) fermented for $24 \mathrm{~h}$ at $30^{\circ} \mathrm{C}$ with the association between Lactobacillus plantarum 1MR20 and C2 (1MR20/C2-ES). 
of ES protein derivatives, which were liberated through proteolysis during lactic acid bacteria fermentation.

\section{Cytotoxicity and immunmodulatory activities}

Preliminarily, the citoxicity of freeze dried ES fermented with $L$ b. plantarum POM1, 1 MR20 and C2 were assayed towards human colon adenocarcinoma Caco-2 cells. The proliferation of Caco-2 cells was determined through MTT assay. Cells were plated at low density $\left(5 \times 10^{4}\right.$ cells per well) into EMEM, without phenol red, and treated with various concentrations $(1-500 \mu \mathrm{g} / \mathrm{ml})$ of ES for 24, 48 and $72 \mathrm{~h}$. Compared to basal serum free medium (control), incubation with $1-500 \mu \mathrm{g} / \mathrm{ml}$ of fermented ES did not significantly $(P>0.05)$ affect cell proliferation (data not shown). The same result was found after treatment with ES-CT.

Regarding immune-modulatory activity, the treatment with fermented ES $(1,10$ and $50 \mu \mathrm{g} / \mathrm{ml})$ exerted a modulatory effect on Caco-2 cells (Figure 4A, B and C). The significance of this effect was evaluated in comparison with the treatment of Caco- 2 cells by basal medium, which contained containing LPS $(5 \mu \mathrm{g} / \mathrm{ml})$ (control). The exposition for $16 \mathrm{~h}$ to ES fermented with $L b$. plantarum 1MR20significantly $(P<0.05)$ decreased the expression of $T N F-\alpha$ gene (Figure $4 \mathrm{~A})$. The activity was significantly $(P<0.05)$ higher than that of ES-CT. After 24 and $48 \mathrm{~h}$, the highest immune-modulatory activity was found for ES fermented with 1MR20 $(1 \mu \mathrm{g} / \mathrm{ml})$ (Figure 4B and $4 \mathrm{C})$. The ES fermented with the association between the two strains 1 MR20 and C2-ES had an effect similar to the ES fermented with strain 1MR20 alone Nevertheless, the effect was higher when the concentration of $50 \mu \mathrm{g} / \mathrm{ml}$ was assayed for $48 \mathrm{~h}$ of incubation.

\section{Discussion}

Health benefits from fermented plant materials are usually expressed either directly, through interaction of ingested live microorganisms with the host (probiotic effect), or indirectly as the result of the ingestion of microbial metabolites, which are synthesized during fermentation (biogenic effect) [31]. To the best of our knowledge, this is the first study reporting the capacity of lactic acid bacteria to release bioactive compounds during fermentation of Echinacea spp.

Under optimal processing conditions, microorganisms may contribute to plant functionality through their enzyme portfolio, which promotes the release of various metabolites, such as free amino acids and vitamins [31]. Bioactive peptides and $\gamma$-amino butyric acid (GABA) may be released during food processing at levels higher than the physiological threshold, thus exerting various in vivo health benefits [31].

Besides well-known positive effects during food fermentation (e.g., dairy products, fermented meats and leavened baked goods), lactic acid bacteria are recently used to synthesize GABA from grape must [25], isoflavone, aglycones and equol from soy milk, antioxidant and anti-hypertensive peptides, and lunasin from various cereal and pseudo-cereal flours [26,32,33]. Strains of Lactobacillus plantarum, previously isolated from vegetable matrices that are particularly rich of polyphenol compounds [34-36], were used as starters. The concentration of fermentable carbohydrates of Echinacea powder was enough to allow bacterial growth but to get optimal fermentation performances, yeast extract was added. The concentration of fermentable carbohydrates of Echinacea powder was enough to allow bacterial growth.

Antimicrobial and antioxidant activities were investigated during fermentation and compared to nonfermented Echinacea suspension. Echinacea suspensions fermented with $L b$. plantarum POM1 and, especially, strain $\mathrm{C} 2$ exhibited a marked antimicrobial activity towards Gram-positive and -negative bacteria,while it was very low towards fungi. According to literature data [37-40], the concentration of polyphenol compounds largely varies among commercial products containing Echinacea spp. Genetic variation and environmental inputs (e.g., light, temperature, agronomic practices) are considered the main factors affecting the levels of caffeic acid and its derivatives. Drying temperature, extraction methods, formulation and storage conditions may also be responsible for this variability. Overall, the radical scavenging activity of polyphenols is mainly influenced by the number of hydroxyl groups of the aromatic ring $[41,42]$. The radical scavenging activity of the methanol extracts of Echinacea suspensions was high and almost similar between fermented and non-fermented preparations. The only exception was represented by fermentation with $L b$. plantarum $1 \mathrm{MR} 20$, which also caused an increase of antioxidant activity of the methanol extract. A marked inhibition of the linoleic acid peroxidation was also found during eight days of incubation. Overall, this antioxidant potential had to be mainly attributed to inherent polyphenols from the Echinacea matrix, which are solubilized with ethanol or methanol [1]. On the contrary, the antioxidant activity of water-soluble extracts was markedly affected by lactic acid bacteria fermentation. When $L b$. plantarum $1 \mathrm{MR} 20$ was used as starter, the DPPH radical scavenging activity was at least twice than that of the non-fermented Echinacea suspension. MTT assays on mouse fibroblasts showed that the protective effect towards induced oxidative stress by freeze dried Echinacea suspension fermented with $L b$. plantarum $1 \mathrm{MR} 20$ was higher than that of nonfermented sample and also higher than that of $\alpha$-tocopherol, which was used at the same concentration.

Aiming at combining antimicrobial and antioxidant activities, Lb. plantarum C2 and 1MR20 were used in 

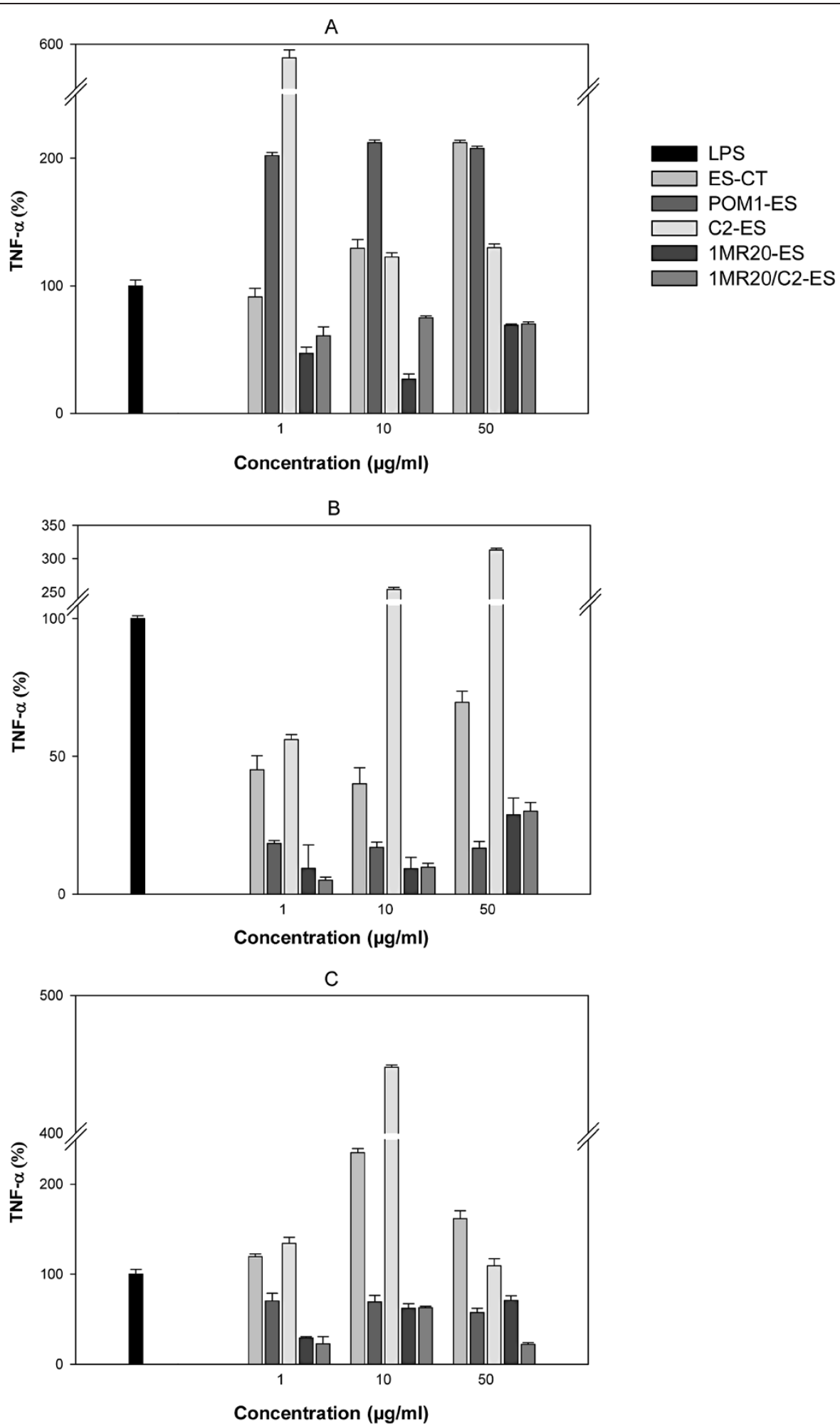

Figure 4 Expression of TNF-a gene of Caco-2 cells. The expression was analyzed after treatment with Echinacea suspension (ES) (1-50 $\mu \mathrm{g} / \mathrm{ml})$ for 16 (A), 24 (B), and $48 \mathrm{~h}(\mathbf{C})$, as determined by RT-PCR. ES fermented for $24 \mathrm{~h}$ at $30^{\circ} \mathrm{C}$ with Lactobacillus plantarum 1MR20 (1MR20-ES), C2 (C2-ES) and POM1 (POM1-ES), and with the association between strains 1MR20 and C2 (1MR20/C2-ES) were assayed. ES-CT, chemically acidified ES, without bacterial inoculum, and incubated for $24 \mathrm{~h}$ at $30^{\circ} \mathrm{C}$, was the control. Results were expressed as percent ratio to lipopolysaccharide (5 $\left.\mu \mathrm{g} / \mathrm{ml}\right)(\mathrm{LPS})$ treated cells (LPS). Data are the means of three independent experiments twice analysed. 
association to ferment the Echinacea suspension. The fermentation favored the liberation of high levels of free amino acids and peptides, which increased ca. 5-6 times compared to non-fermented suspension. The protocol used for purification demonstrated that compounds responsible for antimicrobial activity had low molecular masses and were affected by treatment with digestive enzymes. A mixture of peptides, having 7 to 12 amino acid residues, was identified. All the sequences were encrypted in plantaricins $\mathrm{PlnH}$ or PlnG, which are expressed via the conserved part of the bacteriocin loci and which are responsible for antimicrobial activities of Lb. plantarum strains [43]. The molecular mechanism via quorum sensing regulation of constitutive plantaricin synthesis by $L b$. plantarum $\mathrm{C} 2$ was recently described [44]. Although the functions of $\mathrm{PlnH}$ and $\mathrm{PlnG}$ are already described in the literature [43], no information is available on the activity of their hydrolysis products. In some cases, the bioactivity of hydrolysis products is higher than that of the native precursor $[27,45]$. The synergistic activity of a mixture of peptides is frequently expected $[27,45]$. The MIC of the purified fraction, which contained the mixture of the identified peptides, was comparable to the values reported for similar compounds [46].

During RP-FPLC purification, the antioxidant activity of the water-soluble extract from Echinacea suspensions was distributed in a large number of fractions, and was proportional to the peptide concentration. The contribution of various bioactive compounds was hypothesized. Since polyphenols show variable solubility in water and organic solvents [1], a contribution from water-soluble polyphenols, was not excluded. Nevertheless, a conspicuous part of the antioxidant activity was lost through treatment with digestive enzymes. Fermentation promoted a marked increase of peptides concentration, which were distributed throughout the acetonitrile gradient. Previously, several peptides were shown to possess antioxidant capacity [45]. Antioxidant peptides from vegetable matrices are considered to be safe and healthy compounds with low molecular weight, low cost, high activity and easy absorption. Compared to antioxidant enzymes, peptides have higher stability under various environmental conditions and no hazardous immunoreaction due to their simpler structure [45]. The use of protein hydrolysates obtained through fermentation has been already proposed for nutraceutical purposes [45]. Non purified protein hydrolysates have certain benefits over purified peptides. The absorption of peptides, in fact, increases in the presence of sugars and amino acids, and as the consequence, also the antioxidant activity [45]. The exact mechanism underlying the antioxidant activity of peptides is not fully understood. It was hypothesized that they act as inhibitors of lipid peroxidation [45], scavengers of free radicals [45] and chelators of transition metal ions [45]. Antioxidant peptides may protect cells from damage by Reacting Oxygen Species (ROS) through gene induction.

MTT assay on Caco-2 cells demonstrated the absence of cytotoxicity for a wide range of concentrations of Echinacea suspension. The immune-modulatory effect of Echinacea extracts was proven through in vitro and in vivo assays [10]. It might be associated with various compounds such as polysaccharydes, alkylamides and caffeic acid derivatives. Fermentation of Echinacea suspension, especially with $L b$. plantarum 1MR20, markedly affected the expression of TNF- $\alpha$ by Caco- 2 cells. The in vitro assay was carried out using LPS from $E$. coli, which represents the principal shock inducing factor from the outer membrane of Gram-negative bacteria. Pro-inflammatory cytokines derived from LPS-stimulated cells are responsible for lethal effects as well as for the generation of intermediate signals, which amplify the cellular response by triggering the production of chemokines [47]. TNF- $\alpha$ is a pleiotropic inflammatory cytokine, which mediates inflammation, immune-response and apoptosis [48]. A large spectrum of diseases involved the over production or the persistent activation of TNF- $\alpha$ [49]. This cytokine possesses both growth stimulating and inhibitory properties, and its release is self-regulatory. For instance, TNF- $\alpha$ induces neutrophil proliferation during inflammation and also neutrophil apoptosis upon binding the TNF-R55 receptor [50]. Low levels of TNF- $\alpha$ may contribute to homeostasis by regulating the body circadian rhythm [51].

\section{Conclusions}

Nutraceutical industry and preventive medicine are currently showing a marked interest for natural antimicrobial, antioxidant and immune-modulatory compounds. The demand for dietary phytonutrients encourages the exploitation of plant potential through lactic acid fermentation [1]. Under this perspective, this study demonstrates how the antimicrobial, antioxidant and immune-modulatory properties of Echinacea spp. are enhanced through the fermentation by selected lactic acid bacteria. Novel applications as functional food dietary supplements or pharmaceutical preparations could be expected.

\section{Methods}

\section{Microorganisms and culture conditions}

Lactobacillus plantarum POM1, 1MR20 and C2 were previously isolated, identified by partial sequencing of $16 \mathrm{~S}$ rRNA, recA, pheS and rpoA genes, and selected from tomato, pineapple and carrot, respectively [34-36]. Strains were cultivated for $24 \mathrm{~h}$ at $30^{\circ} \mathrm{C}$ on MRS broth (Oxoid, Basingstoke, Hampshire, United Kingdom). When used for fermentation, lactic acid bacteria cells were cultivated until the late exponential phase of 
growth was reached (ca. $10 \mathrm{~h}$ ), washed twice in $50 \mathrm{mM}$ phosphate buffer, pH 7.0, and re-suspended in the liquid substrate. Enumeration of lactic acid bacteria was carried out by plating onto MRS agar at $30^{\circ} \mathrm{C}$ for $48 \mathrm{~h}$.

\section{Fermentation media}

The commercial powder of Echinacea purpurea (L.) Moench (Epo S.r.l., Milano, Italy) was used as the substrate for fermentation. Echinacea powder suspension (ES) $(5 \%$, wt/vol) was made in (i) distilled water; (ii) distilled water, which contained $0.4 \%$ (wt/vol) yeast extract (Oxoid); or (iii) grape must (1\% of total carbohydrates). ES was sterilized at $121^{\circ} \mathrm{C}$ for $15 \mathrm{~min}$ and inoculated with lactic acid bacteria strains at the initial cell density of ca. $1 \times 10^{8} \mathrm{CFU} / \mathrm{ml}$. As preliminarily shown, lower inoculums did not ensure the same functional activities (data not shown). Fermentation was allowed at $30^{\circ} \mathrm{C}$ for $24 \mathrm{~h}$, under stirring conditions $(120 \mathrm{rpm})$. ES, without bacterial inoculum, and chemically acidified with lactic acid (final pH 4.0), was incubated under the same conditions and used as the control (ES-CT).

\section{Kinetics of growth and acidification}

Kinetics of growth and acidification were determined and modelled in agreement with the Gompertz equation, as modified by Zwietering et al. [52]: $y=k+\mathrm{A} \exp \{-\exp$ $\left[\left(\mu_{\max }\right.\right.$ or $\left.\left.\left.\mathrm{V}_{\max } \mathrm{e} / \mathrm{A}\right)(\lambda-\mathrm{t})+1\right]\right\}$; where $y$ is the growth expressed as $\log \mathrm{CFU} / \mathrm{g} / \mathrm{h}$ or the acidification rate expressed as $\mathrm{dpH} / \mathrm{dt}$ (units of $\mathrm{pH} / \mathrm{h}$ ) at the time $t ; k$ is the initial level of the dependent variable to be modelled $(\log \mathrm{CFU} / \mathrm{g}$ or $\mathrm{pH}$ units); $A$ is the cell density or $\mathrm{pH}$ (units) variation (between inoculation and the stationary phase); $\mu_{\max }$ or $\mathrm{V}_{\max }$ is the maximum growth rate expressed as $\Delta \log \mathrm{CFU} / \mathrm{ml}$ h or the maximum acidification rate expressed as $\mathrm{dpH} / \mathrm{h}$, respectively; $\lambda$ is the length of the lag phase measured in hours. The experimental data were modelled by the non-linear regression procedure of the Statistica 8.0 software (Statsoft, Tulsa, USA).

\section{Characterization of Echinacea powder suspension (ES)}

Aliquots $(1 \mathrm{ml})$ of ES were centrifuged at $10,000 \times \mathrm{g}$ for $10 \mathrm{~min}$. The supernatant (water-soluble extract, WSE) was filtered through a Millex-HA $0.22-\mathrm{mm}$ pore size filter (Millipore Co., Bedford, MA). The concentration of glucose, fructose and sucrose was determined through HPLC analysis, using an ÄKTA Purifier system (GE Healthcare) equipped with a Spherisorb column (Waters, Millford, USA) and a Perkin Elmer 200a refractive index detector. Elution was at $32^{\circ} \mathrm{C}$ with a flow rate of $1 \mathrm{ml} / \mathrm{min}$, using acetonitrile $80 \%$ as the mobile phase [53].

Organic acids were determined by HPLC, using an ÄKTA Purifier system (GE Healthcare) equipped with an Aminex HPX-87H column (ion exclusion, Biorad) and a UV detector operating at $210 \mathrm{~nm}$. Elution was at $60^{\circ} \mathrm{C}$ with a flow rate of $0.6 \mathrm{ml} / \mathrm{min}$, using $10 \mathrm{mM}$ $\mathrm{H}_{2} \mathrm{SO}_{4}$ as the mobile phase [54]. Peaks were identified by comparing elution times and spiking samples with known quantities of standard solutions of acetic and lactic acid. Total and individual free amino acids were analysed by a Biochrom 30 series Amino Acid Analyzer (Biochrom Ltd., Cambridge Science Park, England), with a Na-cation-exchange column (20 by $0.46 \mathrm{~cm}$ inner diameter) as described by Rizzello et al. [55].

To determine the gross composition samples were previously freeze-dried. Dry matter was assessed by an infrared moisture analyzer MAC 110/NP (Radwag, Poland). Total nitrogen was measured by the Kjeldahl method no. 920.87 [38], using a VELP DK6 heating digester and a VELP UDK 130 distillation system (VELP Scientifica, Usmate Milano). Ash was determined by gravimetric method AOAC no. 923.03 [38]. The fat content was measured by solvent extraction, using a Soxhlet extraction unit.

\section{DPPH radical scavenging activity}

The 1,1-diphenyl-2-picrylhydrazyl (DPPH) radical scavenging activity of ES was determined both on methanol extract (ME) and WSE. Five milliliters of ES were mixed with $50 \mathrm{ml}$ of $80 \%$ methanol to get ME. The mixture was purged with nitrogen stream for $30 \mathrm{~min}$, under stirring condition, and centrifuged at $4,600 \times g$ for $20 \mathrm{~min}$. ME were transferred into test tubes, purged with nitrogen stream and stored at ca. $4^{\circ} \mathrm{C}$ before analysis. The concentration of total phenols was determined as described by Slinkard and Singleton [56]. It was expressed as gallic acid equivalent. The free radical scavenging capacity was determined using the stable 2,2-diphenyl-1picrylhydrazyl radical ( $\left.\mathrm{DPPH}^{\circ}\right)$, as reported by $\mathrm{Yu}$ et al. [57]. The reaction was monitored by reading the absorbance at $517 \mathrm{~nm}$ every $2 \mathrm{~min}$ for $30 \mathrm{~min}$. A blank reagent was used to verify the stability of $\mathrm{DPPH}^{*}$ over the test time. The absorbance value measured after 10 min was used for the calculation of the $\mu$ moles $\mathrm{DPPH}^{*}$ scavenged by extracts. The absorbance value in the presence of the extract was also determined over $30 \mathrm{~min}$ and compared with $75 \mathrm{ppm}$ butylated hydroxytoluene (BHT) as the antioxidant reference.

The scavenging effect of freeze dried WSE on DPPH ${ }^{*}$ free radical was measured according to the method of Shimada et al. [58], with some modifications. Freezedried samples were first dissolved in $0.1 \mathrm{M}$ phosphate buffer $\mathrm{pH} 7.0$ at the final concentration of $1 \mathrm{mg} / \mathrm{ml}$ of peptides, and then $2 \mathrm{ml}$ were added to $2 \mathrm{ml}$ of $0.1 \mathrm{mM}$ DPPH, which was dissolved in $95 \%$ ethanol. The mixture was shaken and left at room temperature for $30 \mathrm{~min}$. The absorbance was read at $517 \mathrm{~nm}$. The absorbance measured after $10 \mathrm{~min}$ was used for the calculation of the DPPH scavenged by WSE [53]. More the absorbance 
was low, higher it was the DPPH scavenging activity. The scavenging activity was expressed as follows: DPPH scavenging activity $(\%)=[$ (blank absorbance - sample absorbance) / blank absorbance] × 100. BHT (1 mg/ml) was used as the antioxidant reference.

\section{Inhibition of linoleic acid autoxidation}

The antioxidant activity of ME and WSE was also measured according to the method of Osawa and Namiki [59], with some modifications. Freeze dried WSE or ME (1 mg) was suspended into $1 \mathrm{ml}$ of $0.1 \mathrm{M}$ phosphate buffer ( $\mathrm{pH} 7.0)$, and added to $1 \mathrm{ml}$ of linoleic acid (50 mM), previously dissolved on ethanol (99.5\%). Incubation in glass test tube, tightly sealed with silicone rubber cap, was allowed at $60^{\circ} \mathrm{C}$ in the dark for 8 days. The degree of oxidation was determined by measuring the value of ferric thiocyanate, according to Mitsuta et al. [60]. One hundred microliters of the above sample were mixed with $4.7 \mathrm{ml}$ of $75 \%(\mathrm{v} / \mathrm{v})$ ethanol, $0.1 \mathrm{ml}$ of $30 \%(\mathrm{w} / \mathrm{v})$ ammonium thiocyanate and $0.1 \mathrm{ml}$ of $0.02 \mathrm{M}$ ferrous chloride, dissolved in $1 \mathrm{M} \mathrm{HCl}$. After $3 \mathrm{~min}$, the color development (degree of linoleic acid oxidation) was measured spectrophotometrically at $500 \mathrm{~nm}$. BHT and $\alpha$-tocopherol (1 $\mathrm{mg} / \mathrm{ml}$ ) were used as the antioxidant references. A negative control (without antioxidant) was also considered. The inhibition effect was expressed as follows: inhibition of linoleic acid autoxidation (\%) $=[$ (negative control absorbance - sample absorbance) / negative control absorbance] $\times 100$.

\section{Viability of oxidation-induced cells}

Mouse fibroblasts (Balb 3T3, clone A31, ATCC CCL163TM) were cultured under humidified atmosphere $(5 \%$ $\left.\mathrm{CO}_{2}, 37^{\circ} \mathrm{C}\right)$, using Dulbecco's Modified Eagle Medium (DMEM), which was supplemented with $10 \%(\mathrm{w} / \mathrm{v})$ calf bovine serum (CBS), $1 \%$ penicillin $(10,000 \mathrm{U} / \mathrm{mL}) /$ streptomycin $(10,000 \mathrm{U} / \mathrm{mL})$ mixture, and $1 \%$ non-essential amino acid solution (NEAA). The culture medium was renewed every two days and after four passages the cultures were used for viability assays. Cell viability was measured using the MTT (3-(4,5-dimethyl-2-yl)-2,5diphenyltetrazolium bromide) method [61]. The capacity of succinate dehydrogenase to convert 3-(4,5-dimethylthiazol2-yl)-2,5-diphenyltetrazolium bromide into visible formazan crystals was assessed. For MTT assay, cells were seeded into 96-well plate (Becton Dickinson France S.A., Meylan Cedex, France) at the density of $5 \times 10^{4}$ cells/well and incubated for $24 \mathrm{~h}$. Subsequently, cells were treated with resuspended freeze dried ES and incubated for further $16 \mathrm{~h}$. The concentration of ES in the reaction mixture varied from 1, 10, 50, 100, 250, 500 and $1000 \mu \mathrm{g} / \mathrm{ml}$. A negative control, without addition of ES, was used. $\alpha$-Tocopherol (250 and $500 \mu \mathrm{g} / \mathrm{ml}$ ) was used as the positive control. Following removal of CBS, cells were exposed to $150 \mu \mathrm{M}$ hydrogen peroxide for $2 \mathrm{~h}$. For each well, $100 \mu \mathrm{l}$ of MTT (0.5 $\mathrm{mg} / \mathrm{ml}$ final concentration), dissolved in DMEM, were added and incubated $\left(37^{\circ} \mathrm{C}, 5 \% \mathrm{CO}_{2}\right)$ in the dark for $3 \mathrm{~h}$. Finally, $100 \mu \mathrm{l}$ of dimethyl sulphoxide (DMSO) were added to dissolve purple formazan product. The solution was shacked in the dark for $15 \mathrm{~min}$ at room temperature. The absorbance of the solution was read at $570 \mathrm{~nm}$ in a microplate reader (BioTek Instruments Inc., Bad Friedrichshall,Germany). Each experiment was carried out in triplicate. Data were expressed as the mean percentage of viable cells compared to the control culture, without oxidative stress.

\section{Antimicrobial activity}

Escherichia coli DSM 30083 and Enterobacter aerogenes DSM 30053 grown on Luria Bertani (LB) broth (Oxoid) at $37^{\circ} \mathrm{C}$, Enterococcus durans DSM 20633 and Yersinia enterocolitica DSM 4780 grown on Brain Hearth Infusion (BHI) (Oxoid) at $37^{\circ} \mathrm{C}$, Weissella confusa DSM 20196 and Leuconostoc lactis DSM 20202 grown on MRS broth (Oxoid) at $30^{\circ} \mathrm{C}$, and Propionibacterium jensenii DSM 20535 grown in sodium-lactate broth at $37^{\circ} \mathrm{C}$, which belong to the Culture Collection of the Leibniz Institute DSMZ (Braunschweig, Germany), and Lactobacillus sakei SAL1 grown on MRS broth at $30^{\circ} \mathrm{C}$, Bacillus megaterium F6 grown on LB broth at $37^{\circ} \mathrm{C}$, Candida krusei DSM 3433 grown on Yeast Extract Peptone Dextrose (YEPD) broth (Oxoid) at $25^{\circ} \mathrm{C}$, and Penicillium roqueforti DPPMAF1 grown on Potato Dextrose Agar (PDA) (Oxoid) at $25^{\circ} \mathrm{C}$, which belong to the Culture Collection of the Department of Soil, Plant and Food Sciences (University of Bari, Italy), were used to assay the antimicrobial activity.

The well-diffusion assay [62] was used to determine the antimicrobial activity of WSE and further partially purified fractions. For $P$. roqueforti DPPMAF1, the hyphal radial growth inhibition assay was used, as previously described by Coda et al. [63]. After this preliminary assay, the antimicrobial activity of WSE fractions was determined through the broth micro-dilution technique [64]. Only bacteria were considered for this assay. Logarithmic phase cells (ca. $\left.10^{8} \mathrm{CFU} / \mathrm{ml}\right)$ were harvested by centrifugation $(8000 \times$ $\mathrm{g}$ for $10 \mathrm{~min}$ ), washed twice with $10 \mathrm{mM}$ phosphate buffer, $\mathrm{pH} 7.0$, and adjusted to $10^{4} \mathrm{CFU} / \mathrm{ml}$. The sterile 96-well microtiter plate was used (Greiner Labortechnik). Fifty microliters of each cell suspension were mixed with $50 \mu \mathrm{l}$ of each fraction, and $100 \mu \mathrm{l}$ of each specific culture broth were added. The estimated peptide concentration of each fraction ranged from 5 to $2000 \mu \mathrm{g} / \mathrm{ml}$. Control wells contained all the components except for the peptide fraction, which was replaced with distilled water (positive control) or with chloramphenicol $(100 \mu \mathrm{g} / \mathrm{ml})$ (negative control). Microplates were incubated at 25,30 or $37^{\circ} \mathrm{C}$ depending on the strain, and growth was monitored 
over $24 \mathrm{~h}$ by measuring the optical density of the culture at $620 \mathrm{~nm}$ using a microplate reader (Dynatech Laboratories, West Sussex, UK). The Minimum Inhibitory Concentration (MIC) corresponded to the lowest concentration of the peptide fraction needed to fully inhibit the bacterial growth. When growth was inhibited, cells were recovered from microplates, washed twice with 10 $\mathrm{mM}$ phosphate buffer, $\mathrm{pH}$ 7.0, and incubated into fresh medium to allow the recovery of growth. All assays were carried out in triplicate.

\section{Purification of antioxidant and antimicrobial compounds}

WSE (ca. $400 \mu \mathrm{l}$ ) was subjected to fractionation by ultrafiltration (Ultrafree-MC centrifugal filter units, Millipore), using membrane sizes of 50, 30, 10 and $5 \mathrm{kDa}$ cut-off (corresponding to fractions $\mathrm{A}, \mathrm{B}, \mathrm{C}$ and $\mathrm{D}$, respectively). Centrifugation was at $10,000 \times g$ for $60 \mathrm{~min}$.

Polyphenols were analyzed using a multi-solvents delivery system controller 600 (Waters, PA, USA), equipped with a PDA 996 (Waters) and a Synergi Hydro $80 \AA$ column, $5 \mu \mathrm{m}$ particle size, $250 \times 4.6 \mathrm{~mm}$ (Phenomenex, CA, USA). Separation was carried out using a binary gradient of $10 \%(\mathrm{v} / \mathrm{v})$ formic acid in water (solvent $\mathrm{A}$ ) and acetonitrile $\left(\mathrm{CH}_{3} \mathrm{CN}\right)$ (solvent $\mathrm{B}$ ). The initial conditions were flow $0.8 \mathrm{ml} / \mathrm{min}$, column temperature $30^{\circ} \mathrm{C}$ and solvent $\mathrm{B}$ $12 \%$; after $1 \mathrm{~min}$, the concentration of $\mathrm{B}$ was linearly increased to $90 \%$ in $35 \mathrm{~min}$. The absorbance between 210 and $400 \mathrm{~nm}$ was acquired.

Peptides were analyzed by Reversed-Phase Fast Performance Liquid Chromatography (RP-FPLC), using a Resource RPC column and an ÄKTA FPLC equipment, with the UV detector operating at $214 \mathrm{~nm}$ (GE Healthcare Bio-Sciences AB, Uppsala, Sweden). Aliquots of WSE, containing ca. $1 \mathrm{mg} / \mathrm{ml}$ of peptides, were added to $0.05 \%(\mathrm{v} / \mathrm{v})$ trifluoroacetic acid (TFA) and centrifuged at $10,000 \times g$ for $10 \mathrm{~min}$. The supernatant was filtered with a $0.22 \mu \mathrm{m}$ pore size filter and loaded onto the column. Gradient elution was carried out at the flow rate of $1 \mathrm{ml} / \mathrm{min}$, using a mobile phase composed of water and $\mathrm{CH}_{3} \mathrm{CN}$, containing $0.05 \%$ TFA. The concentration of $\mathrm{CH}_{3} \mathrm{CN}$ was increased linearly from 5 to $46 \%$ between 16 and $62 \mathrm{~min}$, and from 46 to 100\% between 62 and 72 $\mathrm{min}$. Solvents were removed from collected fractions by freeze drying. The fractions were re-dissolved in sterile water and subjected to assays for antioxidant and antimicrobial activities.

Proteolysis and heat stability of partially purified fractions Partially purified fractions from WSE, which had the highest antimicrobial activity, were subjected to sequential protein hydrolysis by digestive enzymes, according to the method of Pasini et al. [65]. Freeze dried WSE, containing ca. $10 \mathrm{mg}$ of peptides, was suspended into $400 \mu \mathrm{l}$ of $0.2 \mathrm{~N} \mathrm{HCl}(\mathrm{pH} 2.0)$, containing $0.05 \mathrm{mg} / \mathrm{ml}$ of pepsin
(EC 3.4.23.1) (Sigma Aldrich CO., St. Louis, MO), and homogenized with a Sterilmixer Lab (PBI International). After $30 \mathrm{~min}$ of incubation at $37^{\circ} \mathrm{C}$ under stirring conditions $(150 \mathrm{rpm}), 115 \mu \mathrm{l}$ of $1 \mathrm{M}$ boric acid and $0.5 \mathrm{~N}$ $\mathrm{NaOH}$, adjusted to pH 6.8 with $5 \mathrm{~N} \mathrm{HCl}$, which contained $0.25 \mathrm{mg} / \mathrm{ml}$ of pancreatin (Sigma) and $0.0087 \mathrm{mg} / \mathrm{ml}$ of trypsin (EC 3.4.21.4) (Sigma), were added. The resulting $\mathrm{pH}$ was 7.6. Pancreatic digestion was lasting $150 \mathrm{~min}$. Digested sample was heated for $5 \mathrm{~min}$ at $100^{\circ} \mathrm{C}$ and centrifuged at 12,000 $\times \mathrm{g}$ for $20 \mathrm{~min}$, to recover the supernatant. After treatments, the assays for antimicrobial and antioxidant activities were carried out.

\section{Identification of antimicrobial peptides}

Fractions of WSE with the highest antimicrobial activity were subjected to further purification through RP-HPLC, using an ÄKTA Purifier apparatus (GE HealthcareHealthcare Bio-Sciences Corp., Piscataway, New Jersey, USA). The centers of the peaks were collected, freeze dried and used for mass spectrometry analysis. Identification of peptides was carried out by nano-Liquid Cromatography-Electrospray Ionisation-Mass Spectra/Mass Spectra (nano-LC-ESI-MS/ MS), using a Finningan LCQ Deca XP Max ion trap mass spectrometer (ThermoElectron) through the nano-ESI interface. According to manufacturer's instrument settings for nano-LC-ESI-MSMS analyses, MS spectra were automatically taken by Xcalibur software (ThermoElectron), in positive ion mode. MS/MS spectra were processed using the software BioWorks 3.2 (ThermoElectron) generating peaklists suitable for database searches. Peptides were identified using MS/MS ion search of Mascot search engine (Matrix Science, London, England) and NCBInr protein database (National Centre for Biotechnology Information, Bethesda, USA). For identification of peptides the following parameters were considered: enzyme: "none"; instrument type: "ESI-trap"; peptide mass tolerance: $\pm 0.1 \%$ and fragment mass tolerance: \pm 0.5 Da. Results from peptide identification were subjected to a manual evaluation, as described by Chen et al. [66], and the validated peptide sequences explained all the major peaks in the MS/MS spectrum.

\section{Cell viability of human colon adenocarcinoma Caco-2 cells}

Human colon adenocarcinoma Caco-2 cells (ICLC HTL97023) supplied by the National Institute for Cancer Research (Genoa, Italy) were routinely cultured in Eagle's minimum essential medium (EMEM), with Earle's balanced salt solution (EMEM-EBSS), and supplemented with $10 \%$ (wt/vol) heat inactivated fetal bovine serum (FBS), 1\% (wt/vol) NEAA, penicillin $(10,000 \mathrm{U} / \mathrm{ml}) /$ streptomycin $(10,000 \mu \mathrm{g} / \mathrm{ml})$ and $1 \% \mathrm{~L}$-glutamin (basal medium). Cells were maintained in $25 \mathrm{~cm}^{2}$ culture flasks at $37^{\circ} \mathrm{C}$ with $5 \%$ $\mathrm{CO}_{2}$. The culture medium was replaced three times a week. Cell viability was measured according to the MTT 
assay (see elsewhere). After $24 \mathrm{~h}$ seeding on 96 well plate, $80 \%$ confluent Caco-2 cells were exposed to various concentrations $(1,10,50,100,250$ and $500 \mu \mathrm{g} / \mathrm{ml})$ of freeze dried ES. The control was the basal medium. Plates were incubated at $37^{\circ} \mathrm{C}, 5 \% \mathrm{CO}_{2}$, for 24,48 and $72 \mathrm{~h}$. After each treatment, the medium was aspirated and replaced with $100 \mu \mathrm{l}$ per well of MTT solution. MTT was dissolved (5 $\mathrm{mg} / \mathrm{ml}$ ) in FBS and diluted 1:10 in the cell culture medium without phenol red. After $3 \mathrm{~h}$ of incubation, the basal medium was aspirated and $100 \mu \mathrm{l}$ per well of DMSO were added to dissolve purple formazan product. The solution was shacked in the dark for 15 min at room temperature. The absorbance of the solutions was read at $570 \mathrm{~nm}$ in a microplate reader (BioTek Instruments Inc., Bad Friedrichshall, Germany). Each experiment was carried out in triplicate. Data were expressed as the mean percentage of viable cells compared to the culture in basal medium.

\section{RNA extraction and real-time-PCR}

After treatment with ES, the expression of TNF- $\alpha$ from Caco-2 cells was investigated through RT-PCR. When ca. $80 \%$ confluence was reached, Caco-2 cells were harvested with trypsin/EDTA, seeded, at the density of $1 \times 10^{6}$ cells per well, into 12 -well (Becton Dickinson France S.A., Meylan Cedex, France) plates and incubated at $37^{\circ} \mathrm{C}, 5 \% \mathrm{CO}_{2}$, for $24 \mathrm{~h}$. Cells in EMEM medium and EMEM with lipopolysaccharide (LPS) $(5 \mu \mathrm{g} / \mathrm{ml})$ were used as the controls. Freeze dried ES at the concentrations of 1, 10 , and $50 \mu \mathrm{g} / \mathrm{ml}$ was added to $80 \%$ confluent Caco- 2 cells with LPS $(5 \mu \mathrm{g} / \mathrm{ml})$, and incubated at $37^{\circ} \mathrm{C}$ for 16,24 and $48 \mathrm{~h}$. For quantitative real-time PCR (RT-PCR), total RNA from Caco-2 cells was extracted using Tri Reagent (Sigma Aldrich), as described by Chomczynski and Mackey [67]. The cDNA was synthesized from $2 \mu \mathrm{g}$ RNA template in a $20 \mu$ reaction volume, using the High-Capacity cDNA Reverse Transcription Kit (Applied Biosystems, Monza, Italy). Ten microliters of total RNA were added to the Master Mix and subjected to reverse transcription in a thermal cycler (Stratagene Mx3000P Real Time PCR System, Agilent Technologies Italia S.p.A., Milan, Italy). The conditions were as follows: $25^{\circ} \mathrm{C}$ for $10 \mathrm{~min}, 37^{\circ} \mathrm{C}$ for $120 \mathrm{~min}$ and $85^{\circ} \mathrm{C}$ for $60 \mathrm{~s}$. The cDNA was amplified and detected through TaqMan ${ }^{\circledR}$ assay (Applied Biosystems). Hs00174128 m1 (TNF- $\alpha$ ) and Hs999999 m1 (human glyceraldehyde-3-phosphate dehydrogenase, GAPDH) were used for Taqman gene expression assays. Human GAPDH was the housekeeping gene. PCR amplifications were carried out using $40 \mathrm{ng}$ of cDNA on a $20 \mu \mathrm{l}$ of total volume. The mixture reaction contained $10 \mu \mathrm{l}$ of $2 \times$ TaqMan Universal PCR Master Mix, $1 \mu$ l of $20 \times$ TaqMan gene expression assay, $5 \mu \mathrm{l}$ of water and $4 \mu \mathrm{l}$ of cDNA. PCR conditions were as follows: $50^{\circ} \mathrm{C}$ for $2 \mathrm{~min}$ (for optimal AmpErase ${ }^{\circ} \mathrm{UNG}$ activity) and $95^{\circ} \mathrm{C}$ for $10 \mathrm{~min}$, followed by 40 amplification cycles $\left(95^{\circ} \mathrm{C}\right.$ for $15 \mathrm{~s} ; 60^{\circ} \mathrm{C}$ for $\left.1 \mathrm{~min}\right)$. Analyses were carried out in triplicate. The average value of target gene was normalized using GAPDH gene and the relative quantification of the levels of gene expression was determined by comparing the $\Delta$ cycle threshold $(\Delta \mathrm{Ct})$ value [68]. Results were expressed as percent ratio to LPStreated cells.

\section{Statistical analysis}

Data were subjected to one-way ANOVA; pair-comparison of treatment means was achieved by Tukey's procedure at $P<0.05$, using the statistical software, Statistica for Windows (Statistica7.0 per Windows). Student's t-test was used for MTT assay (GraphPAD 6.0 per Windows).

\section{Competing interest}

The authors declare that they have no competing interests.

\section{Authors' contributions}

CGR carried out purification and identification of bioactive compounds and elaboration of the data; RC carried out the experimental design of the work, microbiological analyses, and elaboration of the data; DSM, and PF performed fermentations and microbiological determinations; DP, BM, and GG carried out ex-vivo assays and related experimental procedures; VMP carried out the chemical analyses; RDC and MG were the supervisors and the coordinators of the research units. All authors read and approved the final manuscript.

\section{Author details}

'Dipartimento di Scienze del Suolo, della Pianta e degli Alimenti, University of Bari, Via G. Amendola 165/a, 70126 Bari, Italy. ${ }^{2}$ Agriculture and Livestock Engineering Faculty, Universidad Estatal del Sur de Manabí, Jipijapa 130650 Manabí, Ecuador. ${ }^{3}$ Giuliani S.p.A, Milano 20129 Italy.

Received: 2 March 2013 Accepted: 29 April 2013

Published: 4 May 2013

\section{References}

1. Pellati F, Benvenuti S, Magro L, Melegari M, Soragni F: Analysis of phenolic compounds and radical scavenging activity of Echinacea spp. J Pharm Biomed Anal 2004, 35:289-301.

2. Barrett B: Medicinal properties of Echinacea: a critical review. Phytomedicine 2003, 10:66-86.

3. Dell'Acqua S, Aiello N, Scartezzini F, Albertin V, Innocenti G: Analysis of highly secondary-metabolite producing roots and flowers of two Echinacea angustifolia DC. Var. angustifolia accessions. Ind Crops Prod 2010, 31:466-468.

4. Bauer R, Reminger P: TLC and HPLC analysis of alkamides in Echinacea drugs. Planta Med 1989, 55:367-371.

5. Cheminant A, Zawatzky R, Becker H, Brouillard R: Caffeoyl conjugates from Echinacea species: structures and biological activity. Phytochemistry 1988 27:2787-2794

6. Wagner $H$, Stuppner $H$, Schäfer, Zenk M: Immunologically active polysaccharides of Echinacea purpurea cell cultures. Phytochemistry 1988 27:119-126

7. Classen B, Witthohn K, Blaschek W: Characterization of an arabinogalactan-protein isolated from pressed juice of Echinacea purpurea by precipitation with the $\beta$-glucosyl Yariv reagent. Carbohydr Res 2000, 327:497-504.

8. Matthias A, Gillam EM, Penman KG, Matovic NJ, Bone KM, De Voss JJ, Lehmann RP: Cytochrome P450 enzyme-mediated degradation of Echinacea alkylamides in human liver microsomes. Chem Biol Interact 2005, 155:62-70.

9. Woelkart K, Xu W, Pei Y, Makriyannis A, Picone RP, Bauer R: The endocannabinoid system as a target for alkamides from Echinacea angustifolia roots. Planta Med 2005, 71:701-705. 
10. Dal Toso R, Melandri F: Echinacea angustifolia cell culture extract. Nutrafoods 2011, 10:19-25.

11. Bauer $R$, Reminger $P$, Jurcic $K$, Wagner $H$ : Beeinflussung der phagozytoseaktivität durch Echinacea-extrakte. Phytother 1989, 10:43-48.

12. Maffei Facino R, Carini M, Aldini G, Marinello C, Arlandini E, Franzoi L, Colombo M, Pietta P, Mauri P: Direct characterization of caffeoyl esters with antihyaluronidase activity in crude extracts from Echinacea angustifolia roots by fast atom bombardment tandem mass spectrometry. Farmaco 1993, 48:1447-1461.

13. Maffei Facino R, Carini M, Aldini G, Saibene L, Pietta P, Mauri P. Echinacoside and caffeoyl conjugates protect collagen from free radicalinduced degradation: a potential use of Echinacea extracts in the prevention of skin photodamage. Planta Med 1995, 61:510-514.

14. King PJ, Ma G, Miao W, Jia Q, McDougall BR, Reinecke MG, Cornell C, Kuan J, Kim TR, Robinson WE: Structure-activity relationships: analogues of the dicaffeoylquinic and dicaffeoyltartaric acids as potent inhibitors of human immunodeficiency virus type 1 integrase and replication. Med Chem 1999, 42:497-509.

15. Lin Z, Neamati N, Zhao H, Klryu Y, Turpin JA, Alberham C, Strebel K, Kohn K, Witvrouw M, Panecouque C, Debyser Z, De Clercq E, Rice WG, Pommier Y, Burke TR: Chicoric acid analogues as HIV-1 integrase inhibitors. J Med Chem 1999, 42:1401-1414.

16. Cervellati R, Renzulli C, Guerra MC, Speroni E: Evaluation of antioxidant activity of some natural polyphenolic compounds using the Briggs-Rauscher reaction method. J Agric Food Chem 2002, 50:7504-7509.

17. Speroni E, Covoni P, Guizzardi S, Renzulli C, Guerra MC: Anti-inflammatory and cicatrizing activity of Echinacea pallida Nutt. root extract. J Ethnopharmacol 2002, 79:265-272.

18. NCCAM, National Center for Complementary and Alternative Medicine: Publication No. D271 July 2005 [http://nccam.nih.gov/sites/nccam.nih.gov/ files/Herbs_At_A_Glance_Echinacea_06-14-2012_0.pdf?nav=gsa]

19. Luo XB, Chen B, Yao SZ, Zeng JG: Simultaneous analysis of caffeic acid derivatives and alkamides in roots and extracts of Echinacea purpurea by high-performance liquid chromatography-photodiode array detectionelectrospray mass spectrometry. J Chromatogr A 2003, 986:73-81.

20. Percival SS: Use of Echinacea in medicine. Biochem Pharmacology 2000, 60:155-158.

21. Binns SE, Purgina B, Bergeron C, Smith ML, Ball L, Baum BR, Arnason JT: Light-mediated antifungal activity of Echinacea extracts. Planta Med 2000, 66:241-244.

22. Stanisavljević I, Stojičević S, Veličković D, Veljković V, Lazić M: Antioxidant and antimicrobial activities of Echinacea (Echinacea purpurea L.) extracts obtained by classical and ultrasound extraction. Chin J Chem Eng 2009 17:478-483.

23. See DM, Broumand N, Sahl L, Tilles JG: In vitro effects of echinacea and ginseng on natural killer and antibody-dependent cell cytotoxicity in healthy subjects and chronic fatigue syndrome or acquired immunodeficiency syndrome patients. Immunopharmacology 1997 35:229-235.

24. Misawa M: Plant tissue culture: an alternative for production of useful metabolite. FAO Agricultural Services Bulletin 108. Rome: Food and Agriculture Organization of the United Nations; 1994.

25. Di Cagno R, Mazzacane F, Rizzello CG, De Angelis M, Giuliani G, Meloni M, De Servi B, Gobbetti M: Synthesis of $\gamma$-aminobutyric acid (GABA) by Lactobacillus plantarum DSM19463: functional grape must beverage and dermatological applications. App/ Microbiol Biotechnol 2010, 86:731-741.

26. Di Cagno R, Mazzacane F, Rizzello CG, Vincentini O, Silano M, Giuliani G, De Angelis M, Gobbetti M: Synthesis of isoflavone aglycones and equol in soy milks fermented by food-related lactic acid bacteria and their effect on human intestinal Caco-2 cells. J Agric Food Chem 2010, 58:10338-10346.

27. Coda R, Rizzello CG, Pinto D, Gobbetti M: Selected lactic acid bacteria synthesize antioxidant peptides during sourdough fermentation of cereal flours. Appl Environ Microbiol 2012, 78:1087-1096.

28. Winata A, Lorenz K: Antioxidant potential of 5-N-pentadecylresorcinol. J Food Process Preserv 1996, 20:417-429.

29. Qian ZJ, Jung WK, Kim SK: Free radical scavenging activity of a novel antioxidative peptide purified from hydrolysate of bullfrog skin, Rana catesbeiana Shaw. Bioresour Technol 2008, 6:1690-1698.

30. Sloley BD, Urichuk L, Tywin C, Coutts RT, Pang PK, Shan JJ: Comparison of chemical components and antioxidant capacity of different Echinacea species. J Pharm Pharmacol 2001, 53:849-857.
31. Gobbetti M, Di Cagnoa R, De Angelis M: Functional microorganisms for functional food quality. Crit Rev Food Sci Nutr 2010, 508:716-727.

32. Coda R, Rizzello CG, Gobbetti M: Use of sourdough fermentation and pseudo-cereals and leguminous flours for the making of a functional bread enriched of $\gamma$-aminobutyric acid (GABA). Int J Food Microbiol 2010, 137:236-245.

33. Rizzello CG, Nionelli L, Coda R, Gobbetti M: Synthesis of the cancer preventive peptide lunasin by lactic acid bacteria during sourdough fermentation. Nutr Cancer 2012, 64:111-120.

34. Di Cagno R, Surico RF, Siragusa S, De Angelis M, Paradiso A, Minervini F, De Gara L, Gobbetti M: Selection and use of autochthonous mixed starter for lactic acid fermentation of carrots, French beans or marrows. Int I Food Microbiol 2008, 127:220-228.

35. Di Cagno R, Surico RF, Paradiso A, De Angelis M, Salmon JC, Buchin S, De Gara L, Gobbetti M: Effect of autochthonous lactic acid bacteria starters on health-promoting and sensory properties of tomato juices. Int J Food Microbiol 2009, 128:473-483.

36. Di Cagno R, Cardinali G, Minervini G, Livio Antonielli L, Rizzello CG, Ricciuti P. Gobbetti M: Taxonomic structure of the yeasts and lactic acid bacteria microbiota of pineapple (Ananas comosus L. Merr.) and use of autochthonous starters for minimally processing. Food Microbiol 2010, 27:381-389

37. Bergeron C, Livesey JF, Awang DVC, Arnason JT, Rana J, Baum BR, Letchamo W: A quantitative HPLC method for the quality assurance of Echinacea products on the North American market. Phytochem Anal 2000, $11: 207-215$

38. Luo W, Ang CYW, Gehring TA, Heinze TM, Lin LJ, Mattia A: Determination of phenolic compounds in dietary supplements and tea blends containing Echinacea by liquid chromatography with coulometric electrochemical detection. J AOAC Int 2003, 86:202-208.

39. Gotti R, Pomponio R, Bertucci C, Cavrini V: Simultaneous analysis of the lipophilic and hydrophilic markers of Echinacea plant extracts by capillary electrophoresis. J Sep Sci 2002, 25:1079-1086.

40. Pomponio R, Gotti R, Hudaib M, Cavrini V: Analysis of phenolic acids by micellar electrokinetic chromatography: application to Echinacea purpurea plant extracts. J Chromatogr A 2002, 954:239-247.

41. Wang M, Li J, Rangarajan M, Shao Y, LaVoie EJ, Huang TC, Ho CT: Antioxidative phenolic compounds from Sage (Salvia officinalis). J Agric Food Chem 1998, 46:4869-4873.

42. Wang M, Simon JE, Aviles IF, He K, Zheng QY, Tadmor Y: Analysis of antioxidative phenolic compounds in artichoke (Cynara scolymus L.). J Agric Food Chem 2003, 51:601-608.

43. Diep DB, Straume D, Kjos M, Torres C, Nes IF: An overview of the mosaic bacteriocin pln loci from Lactobacillus plantarum. Peptides 2009 30:1562-1574

44. Rizzello CG, Filannino P, Di Cagno R, Calasso M, Gobbetti M: Quorum sensing regulation of constitutive plantaricin synthesis by Lactobacillus plantarum strains isolated from vegetables. Appl Environ Microbio/ 2013. in press.

45. Sarmadi BH, Ismail A: Antioxidative peptides from food proteins: a review. Peptides 2010, 31:1949-1956.

46. Minervini F, Algaron F, Rizzello CG, Fox PF, Monnet V, Gobbetti M: Angiotensin I-converting-enzyme-inhibitory and antibacterial peptides from Lactobacillus helveticus PR4 proteinase- hydrolized caseins of milk from six species. Appl Environ Microbiol 2003, 69:5297-5305.

47. Xavier AM, Isowa N, Cai L, Dziak E, Opas M, McRitchie DI, Slutsky AS, Keshavjee S, Liu M: Tumor necrosis factor-a mediates lipopolysaccharideinduced macrophage inflammatory protein-2 release from alveolar epithelial cells. Autoregulation in host defense. Am J Respir Cell Mol Biol 1999, 21:510-520.

48. Locksley RM, Killeen N, Lenardo MJ: The TNF and TNF receptor superfamilies: integrating mammalian biology. Cell 2001, 104:487-501.

49. McDermott MF: TNF and TNFR biology in health and disease. Cell Mol Biol 2001, 47:619-635.

50. Murray J, Barbara J, Dunkley S, Lopez A, Van Ostade X, Condliffe I, Haslett C, Chilvers $\mathrm{E}$ : Regulation of neutrophil apoptosis by tumor necrosis factor-a: requirements for TNF-R55 and TNF-R75 for induction of apoptosis in vitro. Blood 1997, 90:2772-2783.

51. Strieter RM, Kunkel SL, Bone RC: Role of tumor necrosis factor-alpha in disease states and inflammation. Crit Care Med 1993, 21:S447-S463.

52. Zwietering MH, Jongeberger I, Roumbouts FM, Van't Riet K: Modelling of bacterial growth curve. Appl Environ Microbiol 1990, 56:1875-1881. 
53. Rizzello CG, Nionelli L, Coda R, De Angelis M, Gobbetti M: Effect of sourdough fermentation on stabilisation, and chemical and nutritional characteristics of wheat germ. Food Chem 2010, 119:1079-1089.

54. Zeppa G, Conterno L, Gerbi V: Determination of organic acids, sugars, diacetyl, and acetoin in cheese by high-performance liquid chromatography. J Agric Food Chem 2001, 49:2722-2726.

55. Rizzello CG, Coda R, Mazzacane F, Minervini D, Gobbetti M: Micronized byproducts from debranned durum wheat and sourdough fermentation enhanced the nutritional, textural and sensory features of bread. Food Res Int 2012, 46:304-313.

56. Slinkard K, Singleton VL: Total phenol analysis: automation and comparison with manual methods. Am J Enol Vitic 1997, 28:49-55.

57. Yu L, Perret J, Harris M, Wilson J, Scott Haley S: Antioxidant properties of bran extracts from Akron wheat grown at different locations. J Agric Food Chem 2003, 51:1566-1570.

58. Shimada K, Fujikawa K, Yahara K, Nakamura T: Antioxidative properties of xanthan on the autoxidation of soybean oil in cyclodextrin emulsion. J Agric Food Chem 1992, 40:945-948.

59. Osawa T, Namiki M: Natural antioxidants isolated from Eucalyptus leaf waxes. J Agric Food Chem 1985, 33:777-780.

60. Mitsuta $\mathrm{H}$, Yasumoto $\mathrm{K}$, Iwami $\mathrm{K}$ : Antioxidative action of indole compounds during the autoxidation of linoleic acid. Eiyo Shohkuryo 1996, 19:210-214.

61. Mosmann T: Toxicity determined in vitro by morphological alterations and neutral red absorption. J Immunol Meth 1983, 65:56-63.

62. Schillinger U, Lucke FK: Antibacterial activity of Lactobacillus sakei isolated from meat. Appl Environ Microbiol 1989, 55:1901-1906.

63. Coda R, Cassone A, Rizzello CG, Nionelli L, Cardinali G, Gobbetti M: Antifungal activity of Wickerhamomyces anomalus and Lactobacillus plantarum during sourdough fermentation: identification of novel compounds and long-term effect during storage of wheat bread. Appl Environ Microbiol 2011, 77:3484-3492.

64. Rizzello CG, Losito I, Gobbetti M, Carbonara T, De Bari MD, Zambonin PG Antibacterial activities of peptides from the water-soluble extracts of italian cheese varieties. J Dairy Sci 2005, 88:2348-2360.

65. Pasini G, Simonato B, Giannattasio M, Peruffo ADB, Curioni C: Modifications of wheat flour proteins during in vitro digestion of bread dough, crumb, and crust: an electrophoretic and immunological study. J Agric Food Chem 2001, 49:2254-2261.

66. Chen Y, Kwon SW, Kim SC, Zhao Y: Integrated approach for manual evaluation of peptides identified by searching protein sequence databases with tandem mass spectra. J Proteome Res 2005, 4:998-1005.

67. Chomczynski P, Mackey K: Modification of the TRI reagent procedure for isolation of RNA from polysaccharide- and proteoglycan-rich sources. Biotechniques 1995, 19:942-945

68. Vigetti D, Viola M, Karousou E, Rizzi M, Moretto P, Genasetti A, Clerici M, Hascall VC, De Luca G, Passi A: Hyaluronan-CD44-ERK1/2 regulate human aortic smooth muscle cell motility during aging. J Biol Chem 2008, 283:4448-4458.

doi:10.1186/1475-2859-12-44

Cite this article as: Rizzello et al:: Lactic acid fermentation as a tool to enhance the functional features of Echinacea spp. Microbial Cell Factories 2013 12:44.

\section{Submit your next manuscript to BioMed Central and take full advantage of:}

- Convenient online submission

- Thorough peer review

- No space constraints or color figure charges

- Immediate publication on acceptance

- Inclusion in PubMed, CAS, Scopus and Google Scholar

- Research which is freely available for redistribution

Submit your manuscript at www.biomedcentral.com/submit
Ciomed Central 